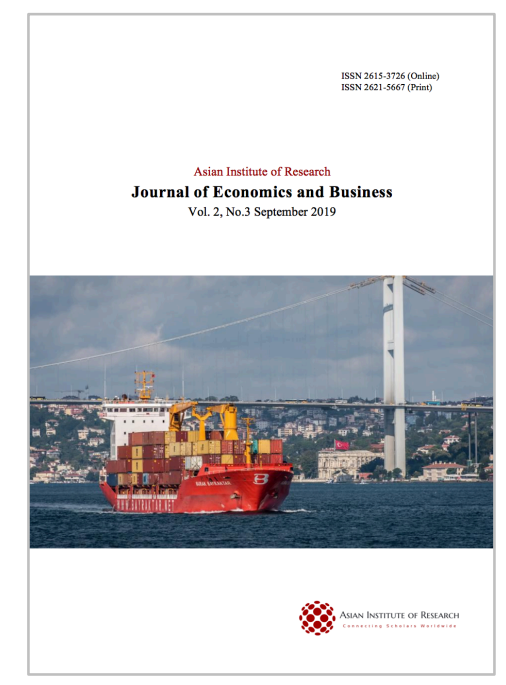

\title{
Journal of Economics and Business
}

\author{
Putra, Yananto Mihadi. (2019), Analysis of Factors Affecting the Interests of \\ SMEs Using Accounting Applications. In: Journal of Economics and Business, \\ Vol.2, No.3, 818-826.
}

ISSN 2615-3726

DOI: 10.31014/aior.1992.02.03.129

The online version of this article can be found at: https://www.asianinstituteofresearch.org/

Published by:

The Asian Institute of Research

The Journal of Economics and Business is an Open Access publication. It may be read, copied, and distributed free of charge according to the conditions of the Creative Commons Attribution 4.0 International license.

The Asian Institute of Research Journal of Economics and Business is a peer-reviewed International Journal. The journal covers scholarly articles in the fields of Economics and Business, which includes, but not limited to, Business Economics (Micro and Macro), Finance, Management, Marketing, Business Law, Entrepreneurship, Behavioral and Health Economics, Government Taxation and Regulations, Financial Markets, International Economics, Investment, and Economic Development. As the journal is Open Access, it ensures high visibility and the increase of citations for all research articles published. The Journal of Economics and Business aims to facilitate scholarly work on recent theoretical and practical aspects of Economics and Business. 


\title{
Analysis of Factors Affecting the Interests of SMEs Using Accounting Applications
}

\author{
Yananto Mihadi Putra \\ ${ }^{1}$ Fakultas Ekonomi dan Bisnis, Program Studi Akuntansi, Universitas Mercu Buana Jakarta, Indonesia \\ Email: yananto.mihadi@mercubuana.ac.id

\begin{abstract}
Technological developments in the world have entered the period of the industrial revolution 4.0. The impact on technological progress is a change in the perspective of manuals, business maps of the world, even in various aspects of economic, social, political, and cultural life. In line with the rapid development of technology, companies, and micro and small and medium enterprises (SMEs) increasingly need technology for the sustainability of their businesses. This study aims to analyse the factors that influence the interest of SMEs using accounting applications. The research method used is a deductive approach. The results of this study cannot yet reject the hypothesis that price, performance, stability, flexibility, implementation, customisation, and vendor support influence the decision to use accounting software.
\end{abstract}

Keywords: Accounting Information System, Accounting Software, SMEs

\section{Introduction}

The development of technology has changed the way and business around the world. Along with the development of these technologies, developments also occur in various aspects of life, for example, in the elements of economic, social, and cultural politics (Kurniawan \& Diptyana, 2011). Currently, technological developments in the world have entered the period of the industrial revolution 4.0 (Tjandrawinata, 2017). There are at least three things that distinguish the industrial revolution 4.0 compared to the previous industrial revolution. These three things are the reasons why the transformation that is happening right now is not an extension of the digital revolution, but rather a new transformation revolution. First, innovation can be developed and spread far faster than before. The speed of the occurrence of breakthroughs in this era occurred on an exponential scale and no longer on a linear scale. Second, the reduction in marginal production costs and the emergence of platforms that can unite and concentrate several scientific fields have been proven to increase work output. Including the entire production, management, and governance system.

Third, the global revolution (information technology) has a significant influence in every field of industry, and even at the system level in many other business sectors (Tjandrawinata, 2017). Therefore, companies must follow the development of information technology to be able to maintain and win the competition (Kurniawan and 
Diptyana, 2011). Furthermore, Kurniawan and Diptyana (2011) explained that it is not only large companies that utilise information technology, but micro, small and medium enterprises (SMEs) also utilise them to play an important role in their efforts to influence the country's economic and industrial growth (Kurniawan and Diptyana, 2011).

SMEs has a significant contributor to the Indonesian National Economics. Besides that, SMEs are also referred to as one of the pillars of economic growth in Indonesia. The contribution of SMEs sector to the gross domestic product (GDP) has been stretching in the last five years (Mutmainah, 2016; Rekarti and Doktoralina, 2017). According to data from the Ministry of Cooperatives and Small and Medium Enterprises (SMEs) in 2016-2017 noted the contribution of the SMEs sector increased from 57.84\% to 60.34\% (Kemenkop-UKM RI, 2018). In addition, the SMEs sector has also assisted in absorbing domestic workers. Employment absorption in the SMEs sector grew from $96.99 \%$ to $97.22 \%$ in the last five years (Mutmainah, 2016).

According to Rekarti, Bahari, Zahari, Doktoralina, and Ilias (2019); Rudiantoro and Siregar (2012), the enormous potential of SMEs is often constrained by capital problems to develop businesses. As a solution, the government runs the SMEs financing program. One such program is the People's Business Credit (KUR). However, the KUR program did not meet the targets and was not well utilised. One reason is the lack of adequate information in the form of financial statements produced. By SMEs, so that banks as KUR suppliers in lending tend to be more careful. Some (Rudiantoro and Siregar, 2012). The importance of applying accounting knowledge in the financial management of SMEs is considered to be poorly understood by entrepreneurs. There are still many small entrepreneurs who have not recorded their business financial statements properly. Some even did not take notes (Susilawati, Yuliati, and Khotmi, 2018). Then, the Government of Indonesia 17/2013 stated that there are obligations for small business actors to do accounting records. One way to deal with technical problems in the financial sector in SMEs is through the adoption of information technology (Kurniawan and Diptyana, 2011; Pramuka, 2012). However, this transition also does not always bring good effects for SMEs. According to Rahmawati and Puspasari (2017), there are also SMEs who consider manual recording to be more effective because given the size of the business activity concerned is relatively small. In Addition, most SMEs feel that the business they are involved in is a small business that is run only to fulfill their daily needs (Rahmawati \& Puspasari, 2017). Thus, many small companies do not have a good financial accounting system.

SMEs are too focused on how to make unique products, while accounting and view of financial systems as a second choice, not as a priority. Then, SMEs also assume that the provision of accounting records will waste time and money. They feel disturbed by financial documents and think that the most important thing is to get the maximum profit (Putri, 2017). SMEs entrepreneurs who have large transactions expressed the opposite view, and they assume that it is not easy to process daily report that much data manually (Aboelmaged, 2014; Ali, Rahman, \& Ismail, 2012; Burgess \& Paguio, 2016). Aboelmaged (2014); Ali, Rahman, and Ismail (2012); Burgess and Paguio (2016) prove that business characteristics, the ability to innovate, external influences, compatibility have a significant effect on SMEs decisions in upgrading software. A computer application (software) program helps meet the needs of SMEs in managing data effectively and efficiently (Lestiawan \& Mahmud, 2014). There are many types of accounting software but do not provide convenience in implemented for SMEs in Indonesia. Therefore, several factors considered in choosing software are some of these factors are price, performance, stability, flexibility, implementation, adjustment, and vendor support (Philip, 2001). Based on the problems that have been explained before, this research wants to explore the factors developed by Philip (2001) that influence the selection of accounting software by SMEs. Therefore, this study explores the use of accounting software by adding elements to the pattern of accounting activities carried out by SMEs based on the value of the transaction activity.

\section{Literature Review}

\subsection{Small Medium Entrepreneurship}

According to Law No.20/2008, SMEs is distinguished by several criteria through its net worth. First, IDR 50 million to IDR 500 million, and that does not include land and business premises, and the total annual sales are at 
most around IDR 300 million. Second, IDR 50 million to IDR 500 million and does not include land and business premises, and the total annual sales are at most around IDR 300 million to IDR 2.5 billion. Third, A medium-sized business is a business that has a wealth of more than Rp 500 million to Rp. 1 billion excluding land and business premises, and total annual sales of a maximum of Rp. 2.5 billion to Rp. 50 billion.

Meanwhile, the Central Statistics Agency defines MSMEs based on the quantity of labour. Small business is a business that has a workforce of 5 people up to 19 people, while medium business is a business that has a workforce of 20 people up to 99 people. Whereas The Central Bank of Indonesia (2015), micro-business is a business run by the poor, owned by families, with local resources and using simple technology, and the business field is easy to get in and out. The amount of the worker, the assets of SMEs Rp 200 million excluding land and business buildings with an annual turnover of less than Rp 1 billion. In addition to its management mandatory by Indonesians and not a legal entity. Meanwhile, medium-sized businesses are defined as having assets of less than Rp. 5 billion for the industrial sector, and assets less than Rp 600 million excluding land, buildings with an annual turnover of less than Rp. 3 billion. Based on these definitions, SME is a form of productive economic enterprise, driven by individuals or business entities. In addition, he must have specific capital, limitations in business development, and not affiliated or controlled by the company.

\subsection{Financial statements}

Based on the Financial Framework and Financial Reporting Framework (KDPPLK) paragraph 7, the intended financial statements are part of the financial reporting process. The financial statements, i.e., including balance sheet, income statement, statement of changes in financial position (in cash flow statements, or cash flow statements), notes and other reports and explanatory material that is an integral part of the financial reporting. Based on the analysis, the existing elements of a financial statement can help decision-makers (Putra, 2018; Setiyawati \& Doktoralina, 2019).

\subsection{Accounting Information}

According to Riahi-Belkaoui (2011), the accounting information as quantitative information about economic entities that are useful for economic decision making and determining choices between alternative actions. Thus, accounting information can be used for strategic planning, management oversight, and operational oversight (Susilawati, Yuliati, and Khotmi, 2018). Based on SAK EMKM (2018) paragraphs 2.2 and 2.8, accounting information must meet the criteria for disclosing economic benefits associated with financial account items that can be sure to flow into or out of the entity so that account items have costs that can be measured reliably.

\subsection{Accounting Information System (AIS) at SMEs}

AIS as a collection (integration) of sub-systems processes transaction data related to financial problems into financial information (Susanto, 2013). AIS also identifies data sets to communicate information to two or more components that interact with each other in achieving goals (Romney, Steinbart, and Cushing, 2015). Therefore, in line with business development that requires timeliness and accuracy in various assessment standards, computer computers are considered as the right choice (Aboelmaged, 2014).

\subsection{Accounting Information System User Capability}

Great personal ability will spur users to use accounting information systems. Cause's the impact of its use of AIS more effective and can increase the satisfaction of user (Kurnia, Choudrie, Mahbubur, \& Alzougool, 2015; Purwati \& Suparlinah, 2017; Romney et al., 2015; Susanto, 2013). The satisfaction of a user can see from the performance, information, economy, control, efficiency, and service (Susanto, 2013). The factors that influence a company in selecting a set of accounting software in general, i.e., Price, Performance, Stability, Flexibility, Implementation, Customization and Vendor support or support from sellers (Maharseni, 2018; Purwati \& Suparlinah, 2017; Romney et al., 2015; Susanto, 2010). The vendor support is all vendor-related activities regarding facilities 
provided by suppliers or sellers including telephone network installations, regular checks, and guarantees for repairs caused by virus attacks (Romney et al., 2015; Susanto, 2010).

\section{Research Methods}

\subsection{Research model}

This research is quantitative research with a deductive approach, with the descriptive statistical test (Ghozali, 2016; Sugiyono, 2015). The data analysed in this study were in the form of individual respondents' opinions. Collection and analysis techniques in the way of views of the subjects studied through the distribution of questionnaires.

\subsection{Population and Sample}

The population in this study were 31,116 SMEs registered in Department of SME and Trade of DKI Jakarta Province (2017). The technique of cluster Random Sampling is used. A total of 850 SMEs became the study sample (Sekaran \& Bougie, 2016; Sugiyono, 2015).

\subsection{Data Types and Sources}

The type of data used in this study is quantitative data. Data sources used in this study are: (a) Primary Data, is data obtained from the first source both from individuals such as the results of a questionnaire (questionnaire) that has been answered by respondents then collected again by researchers; ( b) Secondary data is data that has been collected by other parties and published by the data user community (Sekaran \& Bougie, 2016; Sugiyono, 2015).

\subsection{Definition of Variable Operations}

The dependent variable of this study is the use of accounting software that is directly operated by the user (respondent). The measure of this variable is, through questions related to the use of accounting software on Operational of SMEs. The research variables consist of five types of variables that are considered to influence the decision to use accounting applications, such as:

1) Education level, i.e., elementary school (SD), junior high school (SMP), high school (SMU) or equivalent, Diploma (DIII), Bachelor (SI) and Postgraduate (S2 \& S3). (Rudiantoro \& Siregar, 2012).

2) Company Size. Determining the business size index is to give points to the answers in the questionnaire for questions about the number of employees, company assets, and company sales per year (Rudiantoro and Siregar, 2012).

3) Business duration is shown based on the age of the company based on the year since the establishment of the company up to this research (Rudiantoro and Siregar, 2012).

4) Accounting knowledge is seen based on the formal educational background studied by the owners of SMEs (Rudiantoro and Siregar, 2012).

5) Technology Utilization, seen from the quality of the system, the quality of information, user satisfaction, and the total benefits of the accounting application (Safitri and Setiyani, 2016).

\section{Results and Discussion}

\subsection{Description of Respondent Data}

Profile of respondents in this study include a) gender, $33.3 \%$ male respondents and $66.7 \%$ female respondents; b) age, respondents are dominated between the ages of $31-40$ years which is equal to $47.77 \%$.

4.2 Description of Research Variables 
4.2.1 Description of the Education Level

The internal control variable consists of 1 question divided into four dimensions, i.e., Senior high school, Bachelor, Strata 2, or others. The following data explains the tendency of respondents' answers to the latest education level of SME owners.

Table 3: No of Employee

\begin{tabular}{lrr}
\hline No of Employee & Frequency & Percentage (\%) \\
\hline$<4$ & 318 & 37.41 \\
$5-19$ & 509 & 59.88 \\
$20-99$ & 23 & 2.71 \\
$>100$ & 0 & 0 \\
\hline Total & 850 & 100 \\
\hline \multicolumn{2}{l}{ Sources: Data Processed $(2019)$}
\end{tabular}

Based on Table 1, respondents with a high school education level are the most respondents in the study, amounting to $22.82 \%$, while those who have the lowest level of education $\mathrm{S} 2$ are $2 \%$.

\subsubsection{Description of Company Size}

The company size variable consists of four questions divided into four dimensions based on the characteristics of SMEs. Between the asset dimensions included one question, the number of employees comprised of 1 item, and the sales turnover dimension consisted of 1 subject. The following will be presented trends of respondents' answers on the firm size with frequency distribution and percentage approaches.

\section{a. Asset}

Table 2 presents the recapitulation of respondents' responses submitted to measure company size variables through asset dimensions. This asset dimension consists of 1 question:

Table 2: Respondent Asset Value

\begin{tabular}{lrr}
\hline Value & Frequency & Percentage (\%) \\
\hline$<$ Rp 50 milion & 168 & 19.77 \\
Rp 50 - Rp 500 million & 424 & 49.86 \\
Rp 500 millon - Rp 10 bio & 258 & 30.37 \\
$>$ Rp 10 bio & 0 & 0 \\
& 850 & 100 \\
\hline
\end{tabular}

Sources: Data Processed (2019)

Based on Table 2 it can be seen that the respondents who had assets of $\mathrm{Rp} 50$ million - Rp 500 million were the most respondents in the study, amounting to $49.86 \%$ while those who had assets $<$ Rp50 million were the lowest respondents in this study amounting to $19.77 \%$.

b. Number of employees

Table 3 presents the respondents' responses proposed to measure company size variables through the dimensions of the number of employees employed. This asset dimension consists of 1 question, namely:

Table 3: No of Employee

\begin{tabular}{l|r|r}
\hline No of responde & Frequency & Percentage (\%) \\
\hline$<4$ & 318 & 37.41 \\
$5-19$ & 509 & 59.88 \\
$20-99$ & 23 & 2.71 \\
$>100$ & 0 & 0 \\
\hline Total & 850 & 100 \\
\hline
\end{tabular}

Sources: Data Processed (2019) 
Based on Table 3, it can be seen that respondents who have 5-9 employees are the most respondents in the study, amounting to $59.88 \%$ while those who have 20 - 99 people are the lowest respondents in this study, amounting to $2.71 \%$.

c. Sales Turnover Value

Table 3 presents the recapitulation of respondents' responses proposed to measure the company size variable through the dimensions of the total sales turnover value. This asset dimension consists of 1 question, namely:

Table 4: Sales

\begin{tabular}{lrr}
\hline Sales & Frequency & Percentage (\%) \\
\hline$<$ Rp 300 mio & 392 & 46.12 \\
Rp 300 mio - Rp 2,5 bio & 446 & 52.47 \\
Rp 2,5 r - Rp 50 bio & 12 & 1.41 \\
$>$ Rp 50 bio & 0 & 0 \\
\hline Total & 850 & 100 \\
\hline Sources: Data Processed (2019) & &
\end{tabular}

Based on Table 4, it can be seen that respondents who have a sales turnover value of Rp 300 million - Rp 50 billion are the most respondents in the study, amounting to $52.47 \%$ while those who have the sales turnover value are the lowest respondents in this study amounting to $1.41 \%$.

\subsubsection{Description of the Length of Business}

Variable length of business consists of 1 question divided into 1 dimension, namely the dimension of the length of the business consisting of 1 question. Table 5 about the recapitulation of respondents' responses submitted to measure the company size variable through the dimensions of the length of the business.

Tabel 5: Business Ages

\begin{tabular}{c|r|r}
\hline Business Ages (Year) & Frequency & Percentage (\%) \\
\hline$<5$ & 248 & 29.17 \\
$6-10$ & 370 & 43.53 \\
$10-15$ & 183 & 21.54 \\
$>15$ & 49 & 5.76 \\
\hline Total & 850 & 100 \\
\hline
\end{tabular}

Sources: Data Processed (2019)

Based on Table 5, it can be seen that respondents who have a business length of 6-10 years are the most respondents in the study, amounting to $29.17 \%$, while those who have a business life $>15$ years are the lowest respondents in this study amounting to $5.76 \%$.

\subsubsection{Description of Accounting Knowledge}

The accounting knowledge variable based on educational background consists of 1 question divided into one dimension, namely the educational background dimension, including accounting, management, economics, and others.

Tabel 6: Accounting Knowledge based on academic background

\begin{tabular}{lrr}
\hline & Frequent & Percentage (\%) \\
\hline Accounting & 142 & 16.71 \\
Management & 264 & 31.06 \\
Economic & 348 & 40.94 \\
others & 96 & 11.29 \\
\hline Total & 850 & 100 \\
\hline \multicolumn{2}{l}{ Sources: Data Processed (2019) }
\end{tabular}


Based on Table 6 it can be seen that respondents who have accounting knowledge based on the educational background are only $16.71 \%$, the majority of respondents have an educational experience in other economics that is equal to $40.94 \%$ while in addition to economics it is the minority field of respondents that is equal to 11.29.

\subsubsection{Overview of Utilization of Information Technology}

The information technology utilisation variable consists of 4 questions divided into eight dimensions, which based on experience using Accounting Computer applications, accounting applications used, and respondents' explanation of choosing the accounting application.

Table 7: IT usage

\begin{tabular}{lrr}
\hline & Freqeunt & Percentage (\%) \\
\hline Accounting software & 324 & 38.12 \\
Others & 526 & 61.88 \\
\hline Total & 850 & 100 \\
\hline Sources: Data Processed (2019)
\end{tabular}

4.2.6 Accounting Applications Used

Based on Table 7 it can be seen that respondents have used accounting applications $38.12 \%$ while $61.88 \%$ have not used accounting applications in the process of preparing financial statements for their business results.

Table 8: Application

\begin{tabular}{lll}
\hline & Frequency & Percentage (\%) \\
\hline Zahir Accounting & 88 & 27.16 \\
Accurate Accounting & 62 & 19.14 \\
MYOB & 44 & 13.58 \\
Microsoft Excell & 117 & 36.11 \\
Others & 13 & 4.01 \\
\hline Total & 324 & 100 \\
\hline \multicolumn{2}{l}{ Sources: Data Processed (2019) }
\end{tabular}

From the 324 respondents who had used accounting applications, the most widely used Microsoft Excel applications were $36.11 \%$, then Zahir Accounting 27.16\%, Accurate Accounting 19.14\%, MYOB 13.58\% and other accounting applications $4 \%$. Then the dimensions of the accounting application selection criteria are measured using an ordinal scale through questions by answering Yes and No.

\begin{tabular}{llllll}
\multicolumn{7}{c}{ Tablel 9: Criteria } \\
\hline & Yes & $\%$ & No & $\%$ & Total \\
\hline Business & 204 & 62.96 & 120 & 37.04 & 324 \\
Easy to use & 298 & 91.98 & 26 & 8.02 & 324 \\
Low price & 177 & $54.63 \%$ & 147 & $45.37 \%$ & 324 \\
Report & 188 & 58.02 & 136 & 41.98 & 324 \\
Security & 137 & 42.28 & 187 & 57.72 & 324 \\
\hline \multicolumn{5}{l}{ Sources: Data Processed (2019) }
\end{tabular}

Based on table 9, 62.96\% of respondents use accounting applications because of the needs of their business activities. Furthermore, $91.98 \%$ of respondents stated the ease of use of accounting applications determines the selection of accounting applications. As much as $73.15 \%$ of respondents reported that the price of a more affordable accounting application license affects a variety of accounting applications. The quality of the results of financial statements produced by accounting applications determines the selection of accounting applications used from $58.02 \%$ of respondents. Meanwhile, application security has not been a determining factor in choosing accounting applications where $57.72 \%$ of respondents not to prioritise the security aspects of applications in the selection of accounting applications. 


\section{Conclusions \& Suggestion}

Based on the results of the study note, the level of education, company size, length of business, and accounting knowledge is not a determining factor in the selection of accounting applications. SMEs use accounting applications because of the needs of their business activities, ease of use of accounting applications, the price of more affordable accounting applications, the quality of the results of financial statements produced by accounting applications while application security has not been a determining factor in choosing accounting applications. Suggestion for academics, the results of this study can be used as additional references to enrich knowledge about the factors that influence the use of accounting applications. Limitations in this study include the selection of respondents who are still uneven and knowledge of accounting that is considered not to meet standards. For future research, it is advisable to choose respondents who have accounting knowledge and use more in-depth statistical methods.

\section{References}

Aboelmaged, M. G. (2014). Predicting e-readiness at firm-level: An analysis of technological, organizational, and environmental (TOE) effects on e-maintenance readiness in manufacturing firms. International Journal of Information Management, 34(5), 639-651. https://doi.org/10.1016/j.ijinfomgt.2014.05.002

Ali, A., Rahman, M. S. A., \& Ismail, W. N. S. W. (2012). Predicting continuance intention to use accounting information systems among SMEs in Terengganu, Malaysia. International Journal of Economics and Management, 6(2), 295-320.

Badan Pusat Statistik. (n.d.). Usaha Kecil.

Bank Indonesia. (2015). Profil Bisnis Usaha Mikro, Kecil Dan Menengah (UMKM). Jakarta: Lembaga Pengembangan Perbankan Indonesia-Bank Indonesia.

Burgess, S., \& Paguio, R. (2016). Examining ICT application adoption in Australian home-based businesses: An innovation-decision process approach. Journal of Enterprise Information Management, 29(2), 276-299. https://doi.org/10.1108/JEIM-02-2014-0012

Dinas Koperasi Usaha Kecil dan Menengah serta Perdagangan Provinsi DKI Jakarta. (2017). Laporan Kinerja Pembangunan Koperasi Dan UMKM Di Provinsi DKI Jakarta. Jakarta.

Ghozali, I. (2016). Aplikasi Analisis Multivariete dengan Program IBM SPSS 23, Edisi Delapan. Penerbit Universitas Diponogoro. Semarang.

Indonesia, Republic of. Peraturan Pemerintah (PP) tentang Pelaksanaan Undang-undang Nomor 20 Tahun 2008 tentang Usaha Mikro Kecil dan Menengah (2013). Indonesia.

Indonesia, Republik. (2008). Undang-Undang No. 20 Tahun 2008 tentang Usaha Mikro, Kecil, dan Menengah. Jakarta: Sekretariat Negara.

Kemenkop-UKM RI. (2018). Perkembangan Data Usaha Mikro, Kecil, Menengah (UMKM) dan Usaha Besar (UB) Tahun 2016-2017. Kementerian Koperasi dan UKM RI.

Kurnia, S., Choudrie, J., Mahbubur, R. M., \& Alzougool, B. (2015). E-commerce technology adoption: A Malaysian grocery SME retail sector study. Journal of Business Research, 68(9), 1906-1918. https://doi.org/10.1016/j.jbusres.2014.12.010

Kurniawan, R., \& Diptyana, P. (2011). Telaah Pemanfaatan Software Akuntansi oleh Usaha Kecil Dan Menengah. The Indonesian Accounting Review, 1(2), 107-116.

Lestiawan, H., \& Mahmud. (2014). Purwarupa Pembelajaran Mandiri Sistem Aplikasi Akuntansi Umkm Berbasis Web Dalam Pemberdayaan Usaha Masyarakat Jawa Tengah. Prosiding SNATIF, (2014), 445-452.

Maharseni, N. W. R. (2018). Analisis Faktor-Faktor tingkat Penerimaan dan Penggunaan Aplikasi Akuntansi Berbasis Android menggunakan Pendekatan Technology Acceptance Model.

Mutmainah, D. A. (2016). Kontribusi UMKM Terhadap PDB Tembus Lebih Dari 60 Persen.

Philip, B. (2001). Expert Talk Accounting Software.

Pramuka, B. A. (2012). Adopsi Teknologi Umkm Berorientasi Ekspor Untuk Pelaporan Keuangan: Studi Di Kabupaten Banyumas.

Purwati, A. S., \& Suparlinah, I. (2017). Faktor-Faktor Yang Mempengaruhi Manfaat Penggunaan Aplikasi Akuntansi Dea Untuk Menyusun Laporan Keuangan. Sustainable Competitive Advantage-7 (SCA-7), 7(1), 411-420.

Putra, Y. M. (2018). Pemetaan Penerapan Standar Akuntansi Keuangan EMKM Pada UMKM Di Kota Tangerang Selatan. Jurnal Profita: Komunikasi Ilmiah Akuntansi Dan Perpajakan, 11(2), 201-217.

Putri, A. H. K. (2017). Pengaruh Faktor Latar Belakang Pendidikan Terhadap Kualitas Laporan Keuangan Melalui Pengetahuan AKuntansi Sebagai Variabel Intervening. Ihtiyath: Jurnal Manajemen Keuangan 
Syariah, 1(2), 32-52.

Rahmawati, T., \& Puspasari, O. R. (2017). Implementasi sak etap dan kualitas laporan keuangan umkm terkait akses modal perbankan. Kajian Akuntansi, 1(1), 49-62.

Rekarti, E., Bahari, Z., Zahari, N. M., Doktoralina, C. M., \& Ilias, N. A. (2019). The Sustainability of Muslim Women Entrepreneurs: A Case Study in Malaysia. International Journal of Financial Research, 10(5), 430439.

Rekarti, E., \& Doktoralina, C. M. (2017). Improving Business Performance: A Proposed Model for SMEs. European Research Studies Journal, 20(3A), 613-623.

Riahi-Belkaoui, A. (2011). Accounting Theory. [Nachdr.]. Andover: Thomson.

Romney, M. B., Steinbart, P. J., \& Cushing, B. E. (2015). Accounting Information Systems (13th ed., Vol. 13th). Prentice Hall Upper Saddle River, NJ.

Rudiantoro, R., \& Siregar, S. V. (2012). Kualitas Laporan Keuangan UMKM Serta Prospek Implementasi SAK ETAP. Jurnal Akuntansi Dan Keuangan Indonesia, 9(1), 1-21. https://doi.org/10.21002/jaki.2012.01

Safitri, M. E., \& Setiyani, R. (2016). Pengaruh Motivasi Belajar, Computer Attitude Dan Fasilitas Laboratorium Akuntansi Terhadap Prestasi Belajar Komputer Akuntansi MYOB. Economic Education Analysis Journal, $5(1), 30-43$.

Sekaran, U., \& Bougie, R. (2016). Research Methods for Business: A Skill Building Approach (7th Editio). John Wiley \& Sons.

Setiyawati, H., \& Doktoralina, C. (2019). The importance of quality accounting information management in regional governments in Indonesia. Management Science Letters, 9(12), 2083-2092.

Sugiyono. (2015). Metode Penelitian Kuantitatif, Kualitatif dan $R \& D$. Bandung: Alfabeta.

Susanto, A. (2010). Information Technology for Business and Accounting. Prime Edition. Bandung: Lingga Jaya.

Susanto, A. (2013). Sistem Informasi Akuntansi. Bandung: Lingga Jaya.

Susilawati, D., Yuliati, N. N., \& Khotmi, H. (2018). Faktor-Faktor Yang Mempengaruhi Penggunaan Informasi Akuntansi Pada Usaha Mikro Kecil Menengah (Survei Pada UMKM Di Kecamatan Aikmel Lombok Timur). Jurnal Aplikasi Akuntansi, 2(1), 22-41.

Tjandrawinata, R. R. (2017). Industri 4.0: Revolusi Industri Abad Ini Dan Pengaruhnya Pada Bidang Kesehatan Dan Bioteknologi. Seminar Dan Konferensi Nasional IDEC, 2(6), 512-518. https://doi.org/10.5281/zenodo.49404 